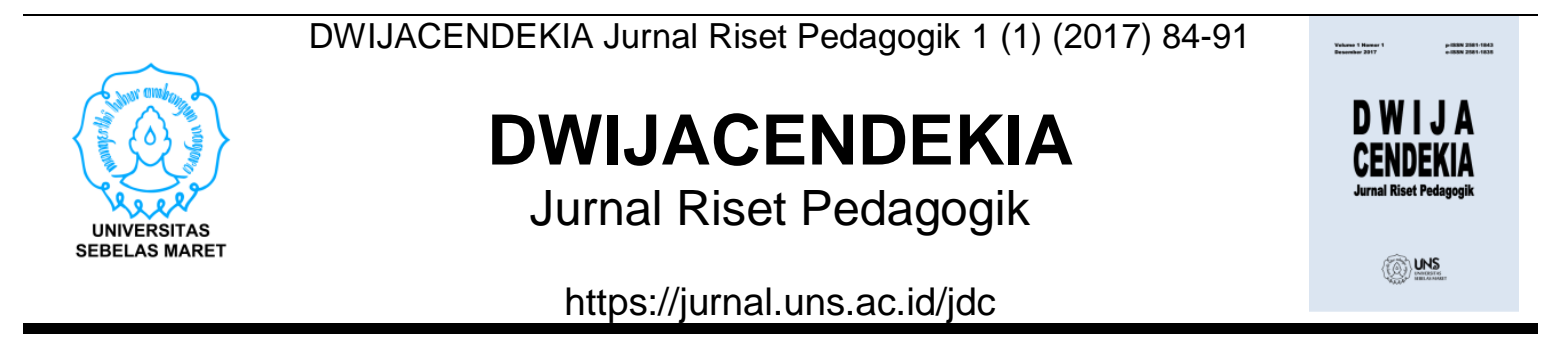

\title{
PENGGUNAAN MEDIA AUDIO VISUAL UNTUK MENINGKATKAN KEMAMPUAN SISWA DALAM MEMAHAMI UNSUR INTRINSIK CERITA DI KELAS VI SDN JOGOSATRU
}

\section{Sriwidayah}

SD Negeri Jogosatru Sidoarjo

\section{Sejarah Artikel}

Diterima 20 Juli 2017

Disetujui 30 Juli 2017

Diterbitkan 1 Agustus 2017

\section{Kata Kunci}

Keterampilan menyimak, media audiovisual, hasil belajar

\begin{abstract}
Abstrak
Adanya permasalahan mengenai rendahnya keterampilan menyimak siswa membuat timbulnya gagasan baru dalam upaya untuk meningkatkan keterampilan menyimak siswa tersebut. Dimana gagasan baru tersebut adalah dengan menggunakan media pembelajaran. Sehingga dapat membangkitkan motivasi serta mengontrol respon siswa. Penerapan media dalam proses pembelajaran keterampilan menyimak adalah dengan menggunakan media VCD dongeng.Dengan latar belakang seperti itulah yang membuat penulis melakukan penelitian untuk mengetahui apakah dengan digunakan media VCD dongeng dapat meningkatkan keterampilan siswa. Hasil peningkatan keterampilan menyimak menggunakan media VCD dongeng yang dicapai oleh siswa sebagai subjek penelitian yang berjumlah 8 anak adalah sebanyak $100 \%$ dari jumlah siswa. Hendaknya media VCD dongeng ini dapat digunakan dalam pembelajaran keteramoilan menyimak agar siswa dapat lebih termotivasi dalam melaksanakan proses menyimak. Harapan penulis semoga artikel ini dapat bermanfaat bagi seluruh pihak umumnya, dan bagi penulis khususnya.
\end{abstract}

\section{Cara Mengutip}

Sriwidayah. (2017). Penggunaan Media Audi Visual untuk Meningkatkan Kemampuan Siswa dalam Memahami Unsur Instrinsik Cerita. DWIJACENDEKIA Jurnal Riset Pedagogik, 1(1), 84-91. 


\section{PENDAHULUAN}

Salah satu kebijakan pendidikan yang dituangkan dalam Propenas 19992004 adalah peningkatan mutu pendidikan nasional. Berbagai upaya untuk meningkatkan mutu pendidikan telah dan akan terus dilakukan, di antaranya dengan melengkapi sekolah-sekolah dengan berbagai sarana dan sumber belajar di sekolah. Hal itu sejalan dengan undangundang No.2 tahun 1989 tentang Sistem Pendidikan Nasional yang mensyaratkan agar setiap satuan pendidikan jalur sekolah menyediakan sarana belajar yang memadai sebagai pendukung pelaksanaan pendidikan.

Sesuai dengan sifatnya, media audio visual memiliki banyak keunggulan dibandingkan dengan media lainnya. Media audio visual dapat membuat konsep yang abstrak menjadi lebih kongkrit, dapat menampilkan gerak yang dipercepat atau diperlambat sehingga lebih mudah diamati, dapat menampilkan detail suatu benda atau proses, serta membuat penyajian pembelajaran lebih menarik, sehingga proses pembelajaran menjadi menyenangkan.

Sejalan dengan perkembangan ilmu pengetahuan dan teknologi, saat ini penggunaan media pendidikan, khususnya media audiovisual, sudah merupakan suatu tuntutan yang mendesak. Hal ini disebabkan sifat pembelajaran yang semakin kompleks. Terdapat berbagai tujuan belajar yang sulit dicapai hanya dengan mengandalkan penjelasan guru. Oleh karena itu, agar pembelajaran dapat mencapaihasil yang maksimal diperlukan adanya pemanfaatan media, salah satunya adalah media audio visual.
Dalam rangka itu maka sesuai tugas dan fungsinya, Pusat Teknologi Komunikasi dan Informasi Pendidikan (PUSTEKKOM) telah mengembangkan sejumlah program video pembelajaran yang ditujukan bagi siswa SD, SLIP, dan SMU. Program tersebut saat ini sudah tersebar di beberapa sekolah, namun kenyataan di lapangan menunjukkan bahwa berbagai media yang ada termasuk program video pembelajaran belum dimanfaatkan secara optimal. Hal ini antara lain disebabkan tidak siapnya sumber daya manusia yang ada di sekolah untuk memanfaatkan program media.

Dalam kegiatan pembelajaran mendengarkan Bahasa Indonesia kehadiran media mempunyai arti penting sebagai penyalur informasi pembelajaran. Kerumitan bahan yang disampaikan kepada peserta didik dapat di atasi dengan bantuan media. Media dapat mewakili apa yang kurang mampu guru ucapkan dengan kata-kata, namun peranan media tidak akan terlihat manakala penggunaannya tidak sejalan dengan isi dan tujuan pembelajaran yang telah dirumuskan. Karena itu, tujuan pembelajaran harus dijadikan sebagai pangkal untuk menggunakan media. Apabila tidak, maka media bukan lagi sebagai alat bantu pembelajaran, tetapi akan menjadi penghambat dalam meningkatkan pengetahuan siswa dalam proses belajar mengajar.

Pembelajaran mendengarkan di sekolah dasar dilaksanakan dengan cara siswa diberi arahan mengenai cara pembelajaran menyimak yang akan dilaksanakan. Kemudian siswa 
diberi gambaran permasalahan yang akan dicari jawabannya, kemudian setelah menyimak siswa diberi evaluasi yang harus dijawab. Kegiatan seperti ini dapat digolongkan kedalam jenis menyimak kritis, yaitu penyimak mencoba menganalisis materi atau bahan yang disimak secara kritis.

Penerapan pelajaran menyimak cerita di SDN Jogosatru di kelas VI dilakukan secara langsung tanpa adanya media pembelajaran. Dalam pelaksanaannya guru langsung membacakan teks bacaan cerita anak, dongeng, maupun cerita rakyat yang ada di buku panduan, kemudian siswa hanya mendengarkannya.Setelah selesai siswa diberi waktu sejenak, kemudian siswa menceritakan kembali isi cerita itu dengan kalimatnya sendiri secara ringkas.Selain aktivitas tersebut setelah guru membacakan teks, siswa menyimaknya sesudah itu mereka diminta menjawab pertanyaan seputar isi cerita.Disitulah guru mengukur tingkat kemampuan siswa dalam memahami isi cerita.

Kegiatan yang dilakukan di atas seringkali mendapatkan hasil evaluasi yang tidak memuaskan. Khususnya pada siswa kelas $\mathrm{VI}$ yang mengalami kesulitan untuk menangkap bunyi bahasa yang diucapkan guru. Dengan adanya kenyataan tersebut peneliti mengupayakan perbaikan pembelajaran menyimak cerita untuk dapat memahami isi dari cerita yang disimak, hal ini ditujukan bagi siswa yang lemah keterampilan menyimaknya. Upaya yang dilakukan peneliti dengan menggunakan media Audio Visual CD cerita legenda Malin Kundang yang diputarkan. Dengan media tersebut siswa dapat melihat sekaligus mendengarkan sehingga siswa mendapat pengalaman langsung dan pengalaman itu dapat membuat pembelajaran lebih bermakna serta diharapkan dapat meningkatkan kemampuan siswa dalam mencari isi dari cerita

\section{METODE PENELITIAN}

Teknik analisis data adalah cara yang digunakan untuk mengolah data yang dikumpulkan dari informan, sehingga data tersebut dapat dikomunikasikan pada masyarakat secara luas. Untuk pemecahan masalah diperlukan tekhnik analisis data yang berkaitan dengan permasalahan yang diteliti. Dalam hal ini peneliti menggunakan teknik analisis data dengan cara deskriptif kualitatif. Dilakukan secara deskriptif sebab hanya menggambarkan obyek yang menjadi pokok permasalahan untuk selanjutnya dianalisis secara kualitatif untuk mencapai kejelasan masalah yang dibahas, sehingga dapat diketahui apakah ada penyimpanganpenyimpangan atau sudah sesuai dengan teori-teori yang ada, selanjutnya dipergunakan sebagai dasar untuk membahas permasalahan dalam penelitian ini.

Teknik analisis data terhadap permasalahan tersebut adalah sebagai berikut :

1. Tahap pengumpulan data

Data-data ini diperoleh selama kita melakukan penelitian, data ini berupa catatan penulis atau melalui rekaman tape recorder saat melakukan wawancara, catatan lapangan saat melakukan pengamatan, foto atau film, dokumen resmi. Dalam penelitian ini yaitu menggunakan media audio visual berupa Video CD 
pada mata pelajaran Bahasa Indonesia.

2. Tahap reduksi data

Pada tahap ini peneliti melakukan pengaturan, pengurutan, memberi kode pada data-data tersebut, pengelompokan, pengkategorian dan berdasarkar telah ditetapkan.

3. Tahap Penyajian Data

Peneliti menyajikan dalam bentuk deskriptif atau gambaran

4. Tahap Penyimpulan Data

Pada tahap ini, peneliti menarik kesimpulan dari gambaran data yang diperoleh.

Berdasarkan jenis data yang digunakan maatka metode tes menggunakan metode kualitatif yang dianalisis secara kualitatif kemudian

Sesuai dengan judul penelitian ini yaitu "Penggunaan Media Audio Visual Untuk Meningkatkan Kemampuan Siswa dalam Memahami unsur intrinsik Cerita di kelas VI SDN Jogosatru.Maka dalam penelitian ini digunakan pendekatan kualitatif. Pendekatan kualitatif yaitu suatu pendekatan dalam melakukan penelitian yang berorientasi pada gejala kealamian yang dilakukan dilapangan. (Ali, 1983: 159) Berdasarkan judul, peneliti ingin memberi gambaran tentang penggunaan media CD untuk meningkatkan kemampuan siswa dalam memahami isi cerita di kelas $\mathrm{VI}$ SDN Jogosatru.Adapun tempat yang dijadikan sasaran dalam penelitian ini adalah di kelas VI SDN Jogosatru.Dan waktu Penelitian yang digunakan dalam penelitian ini adalah mulai dari kegiatan mengajukan judul penelitian sampai dengan penyusunan laporan secara lengkap. Untuk memperoleh data penelitian yang akurat, maka teknik pengumpulan data yang tepat akan berpengaruh dalam kualitas hasil penelitian. Adapun teknik pengumpulan data yang digunakan observasi, tes hasil belajar dan dokumentasi.

\section{PEMBAHASAN}

Berikut hasil penelitian.

Tabel 1. Data Hasil Tes Kemampuan Menyimak SiswaKelas IV SDN JogosatruSebelum dan Sesudah Menggunakan Media Audio visual

\begin{tabular}{|l|l|l|c|c|}
\hline \multirow{2}{*}{ No } & \multirow{2}{*}{ Nama } & \multirow{2}{*}{$\begin{array}{c}\text { L/ } \\
\text { P }\end{array}$} & \multicolumn{2}{|c|}{$\begin{array}{c}\text { Kemampuan } \\
\text { Menganalisis Cerita }\end{array}$} \\
\cline { 4 - 5 } & & & Sebelum & Sesudah \\
\hline 1 & Jefri & $\mathrm{L}$ & 50 & 80 \\
\hline 2 & Cici & $\mathrm{P}$ & 60 & 80 \\
\hline 3 & Lambang & $\mathrm{L}$ & 35 & 63 \\
\hline 4 & Dewanata & $\mathrm{L}$ & 47 & 63 \\
\hline 5 & Rizki Ridlo & $\mathrm{L}$ & 70 & 85 \\
\hline 6 & Sinta I & $\mathrm{P}$ & 18 & 60 \\
\hline 7 & Siti Yuli & $\mathrm{P}$ & 63 & 72 \\
\hline 8 & Febiola S. & $\mathrm{P}$ & 85 & 94 \\
\hline & Jumlah & & 428 & 597 \\
\hline
\end{tabular}

Dari tabel diatas, untuk mengetahui tingkat keberhasilan siswa dalam kegiatan menyimak dipergunakan prosentase berikut ini :

$$
\begin{aligned}
& P=\frac{n}{N} x 100 \% \\
& \text { Keterangan : } \\
& \mathrm{P} \quad: \text { Persentase yang diberi } \\
& \mathrm{n} \quad: \text { Jumlah nilai yang }
\end{aligned}
$$

diperoleh siswa

$\mathrm{N}$ : Jumlah seluruh siswa 
Tabel 2. Rekapitulasi Hasil Tes Kemampuan Memahami Unsur Intrinsik Cerita Siswa Kelas VI SDN JogosatruSebelum Menggunakan Media Audio Visual.

\begin{tabular}{|l|l|l|c|c|}
\hline No & $\begin{array}{l}\text { Kriteria } \\
\text { Penilaian }\end{array}$ & Nilai & Siswa & $\%$ \\
\hline 1 & $\begin{array}{l}\text { Sangat } \\
\text { memuaskan }\end{array}$ & $\begin{array}{l}85- \\
100\end{array}$ & 1 & 12,5 \\
\hline 2 & Memuaskan & $\begin{array}{l}70- \\
85\end{array}$ & 1 & 12,5 \\
\hline 3 & $\begin{array}{l}\text { Cukup } \\
\text { memuaskan }\end{array}$ & $\begin{array}{l}60- \\
65\end{array}$ & 2 & 25 \\
\hline 4 & $\begin{array}{l}\text { Kurang } \\
\text { memuaskan }\end{array}$ & $\begin{array}{l}40- \\
55\end{array}$ & 2 & 25 \\
\hline 5 & $\begin{array}{l}\text { Sangat tidak } \\
\text { memuaskan }\end{array}$ & $\begin{array}{l}40- \\
35\end{array}$ & 2 & 25 \\
\hline & Jumlah & & 428 & 597 \\
\hline
\end{tabular}

Dengan memperhatikan hasil tes pada kemampuan menyimak mencari unsur intrinsik cerita kelasVI di SDN Jogosatru menunjukkan bahwa nilai rata-rata yang diperoleh sebelum menggunakan media audio visual pembelajaran yaitu dengan nilai 53,5. Maka hal ini ditunjukkan oleh adanya pada kriteria penilaian yaitu :

a. Sangat memuaskan ( 1 orang atau $12,5 \%)$ dengan nilai $(85-100)$

b. Memuaskan ( 1 orang atau 12,5\% ) dengan nilai (70 -85)

c. Cukup memuaskan ( 2 orang atau $25 \%$ ) dengan nilai (55-60)

d. Kurang memuaskan (2 orang atau $25 \%$ ) dengan nilai $(40-55)$

e. Sangat tidak memuaskan orang atau $25 \%$ ) dengan nilai (0 $-35)$

Berdasarkan hasil tes awal, maka peneliti perlu untuk mengadakan perbaikan kemampuan menyimak siswa dalam mencari unsur intrinsik cerita pada mata pelajaran bahasa Indonesia yaitu dengan menggunakan media audio visual pembelajaran berupa VCD cerita rakyat.

Berdasarkan data hasil tes kemampuan menyimak yang kedua yaitu dengan menggunakan media audio visual diperoleh data rata-rata kelas adalah 74,6. Hal ini menunjukkan adanya peningkatan terhadap kemampuan menyimak siswa dalam mencari unsur intrinsik cerita.Dengan menggunakan media audio visual siswa dapat mencari sendiri tokoh dalam cerita, latar, alur, amanat, dan sudut pandang. Hal ini sesuai dengan pernyataan Shymansky dalam suparno (1997) yang mengemukakan bahwa kegiatan belajar adalah kegiatan yang aktif dimana siswa dapat membangun sendiri pengetahuannya, ini merupakan proses menyesuaikan konsep-konsep dan ide-ide baru dengan kerangka berfikir yang telah ada dalam pikiran mereka.

Tabel 3. Rekapitulasi Hasil Tes Kemampuan Memahami Unsur Intrinsik Cerita Siswa Kelas VI SDN JogosatruSesudah Menggunakan Media Audio Visual.

\begin{tabular}{|l|l|l|c|c|}
\hline No & $\begin{array}{l}\text { Kriteria } \\
\text { Penilaian }\end{array}$ & Nilai & Siswa & $\%$ \\
\hline 1 & $\begin{array}{l}\text { Sangat } \\
\text { memuaskan }\end{array}$ & $\begin{array}{l}85- \\
100\end{array}$ & 2 & 25 \\
\hline 2 & Memuaskan & $\begin{array}{l}70- \\
85\end{array}$ & 3 & 37.5 \\
\hline 3 & $\begin{array}{l}\text { Cukup } \\
\text { memuaskan }\end{array}$ & $\begin{array}{l}60- \\
65\end{array}$ & 3 & 37.5 \\
\hline 4 & $\begin{array}{l}\text { Kurang } \\
\text { memuaskan }\end{array}$ & $\begin{array}{l}40- \\
55\end{array}$ & - & - \\
\hline 5 & $\begin{array}{l}\text { Sangat tidak } \\
\text { memuaskan }\end{array}$ & $\begin{array}{l}40- \\
35\end{array}$ & - & - \\
\hline & Jumlah & & 428 & 597 \\
\hline
\end{tabular}

Untuk mengetahui peningkatan kemampuan menyimak siswa dalam mencari unsur intrinsik dari cerita yang lebih rinci, maka penulis akan menjelaskan sebagai berikut : 
a. Siswa yang mendapatkan kriteria sangat memuaskan dengan nilai 85-100 pada tes awal sebelum menggunakan media audio visual sebanyak 2 orang siswa dengan persentase $25 \%$ Hal ini menunjukkan peningkatan kemampuan menyimak siswa kelas VI SDN Jogosatru sebanyak 1 orang dengan persentase 12,5 $\%$.

b. Siswa yang mendapatkan kriteria memuaskan dengan nilai $70-85$ pada tes awal sebelum menggunakan media audio visual sebanyak 3 orang siswa dengan persentase $37,5 \%$ Hal ini menunjukkan adanya peningkatan kemampuan menyimak siswa kelas VI SDN Jogosatru sebanyak 2orang dengan persentase $25 \%$.

c. Siswa yang mendapatkan kriteria cukup memuaskan dengan nilai 60-65 pada tes awal sebelum menggunakan media audio visual sebanyak 3 orang siswa dengan persentase $37,5 \%$ sedangkan pada tes akhir sesudah menggunakan media audio visual menjadi 3 orang dengan persentase $25 \%$ Hal ini disebabkan siswa yang semula mendapatkan nilai $60-65$ pada tes awal mampu meningkatkan nilainya sehingga siswa yang mendapatkan nilai 60-65 berkurang jumlahnya.

d. Begitu juga dengan siswa yang mendapat nilai 40-55 dengan kriteria kurang memuaskan pada tes awal sebanyak 2 orang siswa dengan persentase $25 \%$, pada tes akhir tidak ada orang siswa yang mendapatkan nilai dibawah 55. Hal ini disebabkan siswa yang semula mendapatkan nilai 40 - 55 pada tes awal mampu meningkatkan nilainya sehingga siswa yang mendapat nilai 40-55 berkurang jumlahnya.

e. Siswa yang mendapat nilai 0-35 dengan kriteria sangat tidak memuaskan yang semula berjumlah 1 orang dengan persentase $12,5 \%$ menjadi tidak ada. Hal itu disebabkan siswa yang mendapatkan nilai antara 035 mampu meningkatkan nilainya menjadi lebih baik.

Berdasarkan data observasi yang dilakukan peneliti pada proses pembelajaran berlangsung, dapat diperoleh data terhadap sikap atau tingkah laku siswa dalam mengikuti kegiatan menyimak. Untuk mengetahui sikap siswa dalam mengikuti kegiatan menyimak dengan menggunakan media audio visual dalam mencari unsur intrinsik cerita pada pembelajaran bahasa indonesia secara rinci dapat dijelaskan bahwa :

a. Keantusiasan siswa didalam menerima apersepsi dari tujuan yang hendak dicapai dari kegiatan belajar mengajar berada pada posisi sangat baik.

b. Perhatian siswa terhadap apa yang mereka pelajari berada pada posisi sangat baik.

c. Ketertarikan siswa pada saat menggunakan media pembelajaran yaitu media audio visual berada pada posisi sangat baik.

d. Pencapaian indikator pembelajaran pada posisi baik

e. Keaktifan siswa dalam mengikuti proses pembelajaran berada pada posisi sangat baik

Kosentrasi dan minat siswa dalam kegiatan menyimak pada saat proses pembelajaran berlangsung berada pada posisi sangat baik. 
Tabel 4. Data Hasil Observasi Kegiatan Mencari Unsur Intrinsik Cerita Siswa Kelas VI SDN Jogosatru Dengan Menggunakan Media Audio Visual Menyimak Cerita Dalam VCD Dongeng Pada Pembelajaran Bahasa Indonesia

\begin{tabular}{|c|c|c|c|c|}
\hline \multirow[t]{2}{*}{ No } & \multirow[t]{2}{*}{ Aspek } & \multicolumn{3}{|c|}{$\begin{array}{c}\text { Kriteria } \\
\text { Penilaian }\end{array}$} \\
\hline & & A & B & C \\
\hline 1 & $\begin{array}{lr}\text { Keantusiasan } & \text { siswa } \\
\text { dalam menerima } \\
\text { apersepsi dari tujuan } \\
\text { yang hendak dicapai } \\
\text { dari kegiatan belajar } \\
\text { mengajar }\end{array}$ & V & & \\
\hline 2 & $\begin{array}{ll}\text { Perhatian } & \text { siswa } \\
\text { terhadap apa } & \text { yang } \\
\text { mereka pelajari } & \\
\end{array}$ & V & & \\
\hline 3 & $\begin{array}{l}\text { Ketertarikan siswa } \\
\text { saat menggunakan } \\
\text { media pembelajaran } \\
\text { Audio visual }\end{array}$ & $\mathrm{V}$ & & \\
\hline 4 & $\begin{array}{l}\text { Pencapaian indikator } \\
\text { pembelajaran }\end{array}$ & & V & \\
\hline 5 & \begin{tabular}{ll}
\multicolumn{2}{l}{ Keaktifan siswa dalam } \\
mengikuti & proses \\
pembelajaran &
\end{tabular} & $\mathrm{V}$ & & \\
\hline 6 & $\begin{array}{l}\text { Konsentrasi dan minat } \\
\text { siswa dalam kegiatan } \\
\text { menyimak pada saat } \\
\text { proses pembelajaran }\end{array}$ & $\mathrm{V}$ & & \\
\hline
\end{tabular}

$$
\text { berlangsung }
$$

Dari hasil penelitian yang telah dilakukan dan dengan melihat pembahasan di atas dapat diketahui adanya peningkatan ketrampilan menyimak dan mencari unsur intrinsik cerita pada pembelajaran bahasa Indonesia kelas VISDN Jogosatru.

Hasil penelitian ini menunjukkan bahwa siswa yang diajar dengan mengguanakan media audio visual meningkatkan ketrampilan menyimak untuk mencari unsur intrinsik cerita pada pembelajaran Bahasa Indonesia lebih baik dari pada siswa yang diajar tanpa menerapkan pengunaan media audio visual. Hal ini telah terbukti dari data hasil tes dan hasil observasi yang diperoleh oleh peneliti dan sesuai dengan kajian pustaka manfaat penggunaan media dalam pembelajaran yang salah satunya yaitu meningkatkan kualitas hasil belajar siswa. (Arsyad, 1997: 24-27).

\section{SIMPULAN}

Berdasarkan pada hasil analisis data dan pembahasan sebagaimana diuraikan pada bab sebelumnya, maka dapat disimpulkan bahwa :

1. Penggunaan media audio visual dapat meningkatkan kemampuan siswa dalam mencari isi cerita pembelajaran bahasa Indonesia. Hal tersebut dapat dilihat dari nilai rata-rata yang meningkat dari 53,5 sebelum menggunakan media audio visual menjadi 74,6 sesudah menggunakan media audio visual. Dari data tersebut dapat disimpulkan bahwa kemampuan memahami unsur intrinsik sebuah cerita sesudah menggunakan media audio visual mengalami peningkatan dibandingkan sebelum menggunakan media audi visual.

2. Keantusiasan, perhatian, ketertarikan, konsentrasi, dan minat kelas VI SDN Jogosatru dalam menggunakan media audio visual VCD dongeng pada 
pembelajaran bahasa Indonesia cenderung berada pada posisi yang sangat baik, hal ini bisa dilihat dari hasil observasi. Penggunaan media bagi mereka merupakan pengalaman baru dan siswa menjadi aktif baik dalam menyimak maupun saat mengerjakan tugas.

Dari pembahasan di atas, dapat diberikan saran kepada para pendidik diharapkan mampu :

1. Meningkatkan pembelajaran dengan mengupayakan berbagai media, misalnya dengan menggunakan media audio visual untuk melatih kemampuan berbahasa yang berhubungan dengan aspek ketrampilan mencari isi dari sebuah cerita pada pelajaran bahasa Indonesia.

2. Memanfaatkan penggunaan suatu media audio visual pada pelaksanan pembelajaran sebagai sumber belajar yang baik, dan berupaya agar siswa termotivasi dalam belajar serta dapat menciptakan suasana kelas yang kondusif yaitu pembelajaran yang aktif, kreatif dan menyenangkan.

\section{DAFTAR PUSTAKA}

Ali, Muhammad, 1983. Strategi Penelitian Pendidikan. Bandung : Angkasa

Arikunto, Suharsimi, 2006 . Prosedur Penelitian Suatu Pendekatan Praktek. Jakarta : PT. Rineka Cipta.

Arsyad, Azhar. 1997. Media Pembelajaran. Jakarta : PT Raja Grafindo Persada.

Djamarah, Syaiful Bahri. Zain, Aswan, Strategi Belajar mengajar. Jakarta: PT Rineka Cipta.

Gulo, W. 2002. Strategi Belajar Mengajar. Jakarta: PT Grasindo.

Rustantoro, Tuwuh. 2005. Penyiapan Bahan Ajar Multimedia Pembelajaran (Fisika). Semarang: LPMP Jawa Tengah.
Didag. 2004. Konstruktivisme dalamPembelajaran. Jakarta: Buletin Pusat Perbukuan Depdiknas Vol. 10 tahun 2004.

Sudjana, Nana dan M.A, Ibrahim. 2004. Penelitian dan Penilaian Pendidikan. Bandung : Sinar Baru Algensindo

Soepena, 2003. Belajar dengan $C D$ ROM, suatu Lompatan dalam pendidikan. Jakarta: Buletin Pusat Perbukuan Depdiknas Vol. 8 Tahun 2003.

Hadi, Sutrisno. 1987. Metodologi Research. Yogyakarta : Yayasan Fakultas Psikologi. UGM. 